\title{
Inleiding in die grondslag van die gereformeerde teologie
}

\author{
L.F. Schulze \\ Departement Dogmatologie en Ekklesiologie \\ Potchefstroomse Universiteit vir $\mathrm{CHO}$ \\ POTCHEFSTROOM
}

\begin{abstract}
The basis and object of Reformed theology

Theologv is not a neutral science but should be embedded in the service of the Church. A close relation between theology and the church is clearly visible in the history of the early church until the era of the Reformation. The disintegration of religion and culture (church and world) during the Renaissance received new impetus from the Enlightenment. Consequently, the tie between church and theology was to a large extent dissolved and theology progressively became a 'wordly' rationalistic enterprise, as a concomitant to what happened in the arts ('art pour l'art). In this context the problems of defining theology and science are discussed and the popularity of modern scientific theory is uncovered. Finally it is argued that the basis (grondslag) and object for Reformed theology can only be the Word of God.
\end{abstract}

\section{Inleiding}

Die gereformeerde teologie is inderdaad 'so wyd soos die Heer se genade'. Die konfessionele formulerings van die eerste sewe ekumeniese konsilies van die kerk word aanvaar as deel van die gereformeerde belydenis. By die bakermat van die gereformeerde teologie word dit voluit erken (art. 9, NGB):

Daarom aanvaar ons in hierdie opsig graag die drie belydenisse, naamlik dié van die Apostels, Nicéa en Atanasius, en ook wat die ou vaders in ooreenstemming hiermee besluit het.

In die lofsange van gereformeerde kerke weerklink die oudste liedere van die Christendom: die magnificat, benedictus en nunc dimittis (kyk VG. 
Luk. 1:46 e.v.; 67 e.v.; 2:39 e.v.; art. $69 \mathrm{KO}$; Kruger et al., 1966:408; Cillié, 1983:14, 161; Spoelstra, 1989:372).

Saamgevat: die gereformeerde kerke (as deel van die Protestantse kerke van die Reformasie) staan voluit in die ekumeniese tradisie en vorm deel van die ekumeniese kerk.

Hierbo is afwisselend gepraat van gereformeerde teologie (begrond in die gereformeerde belydenis) en van gereformeerde kerke. Dit noodsaak 'n nadere ondersoek van die verhouding van (universele) kerk en teologie (in die algemeen) waarvan die gereformeerde kerke en gereformeerde teologie 'n deel is.

\section{Kerk en teologie}

In gereformeerde kringe is die uitdrukking bekend: 'Dit is nie die kerk se taak om teologie te beoefen nie'. Klooster het byvoorbeeld in sy referaat tydens die sitting van die GES in Kaapstad (1976) gesê dat die taak van die kerk Woord- en sakramentsbediening en tughandhawing is - "daarom is dit nie die spesifieke taak van die kerk om 'n teologiese wetenskap uit te bou nie" (Malan, 1977:8; kyk ook Heyns \& Jonker, 1977:190-191).

Bogenoemde stelling moet minstens met 'n knippie sout geneem word. Histories gesien, was alle teoloë 'kerkdienaars' - vanaf die Apostoliese Vaders, Apologete, kerkvaders en Middeleeuse teoloë tot by die Reformasie. Reeds vroeg in die 16de eeu (1534) het Bucer die vier ampte (dienste) in die kerk uiteengesit. Dit is deur Calvyn oorgeneem (vgl. Inst. 4.3.4,5) en het in artikel 2 van die Dordtse Kerkorde neerslag gevind, terwyl die diens van die leraars (doctores) in artikel 18 van die Kerkorde omskryf word (Schulze, 1966:310-313; Spoelstra, 1989:120). Die leer van die vier ampte (art. 2, KO) is dus erfenis van die eksegese en oortuiging van die Reformatore - ten spyte van die Rapport van kerkregtelike sake van die Nasionale Sinode van die Gereformeerde Kerke van 1994 wat, sonder gravamen teen die kerkorde, prontuit verklaar: "Die diens van professor is immers 'n spesifisering van die diens van Woordbedienaar, en nie 'n aparte diens nie" (Agenda, 1994:198 - my kursivering).

Dit bly onverklaarbaar waarom die kerkorde die diens van leraars of professore in die teologie vermeld (art. 2) en omskryf (art. 18) as die beoefening van teologie nie die taak van die kerk is nie.

Wat is dan die verhouding tussen kerk en teologie? 
Wentsel (1981:24) bied 'n hele aantal modelle van die verhouding van kerk en teologie. Van die modelle word hier slegs drie bespreek omdat die ander twee as mengvorme beskou kan word (kyk ook Heyns \& Jonker, 1977: 187-198).

2.1 Kerklike fakulteite wat onder beheer van die Rooms-Katolieke biskopskonferensies staan. In die Apostoliese Konstitusie Sapientia christiana (1979) word bepaal:

De canonieke oprichting of goedkeuring van kerkelijke universiteiten en faculteiten is voorbehouden aan de heilige congregatie voor het katholiek onderwys welke hen volgens de normen van het recht bestuurt. (Wentsel, 1981: 24.)

Volgens hierdie model word die universiteit en teologiese fakulteit deur die kerk opgerig en bestuur. Die model vloei voort uit die Roomse opvatting van die prioriteit van die kerk bo die Skrif met die gevolglike magisterium (leergesag) waarkragtens die kerk die Skrif gesagvol kan uitlê. Aan die teologiese fakulteite word (selfs in die eksegese) geleer wat die kerk leer (Heyns \& Jonker, 1977:189).

2.2 Teologiese skole wat op een of ander wyse (kontraktueel) verbind is aan universiteite en (soms) regeringsubsidie ontvang. Die dosente word benoem deur deputate (kuratore en kieskollege) van die algemene sinode van die kerke. Die teologiese skole staan nie onder (kanonieke) kerklike bestuur nie maar onder kerklike toesig en beheer, omdat bedienaars van die Woord daar opgelei word.

Hierdie model word gedra deur die reformatoriese oortuiging van die prioriteit van die Skrif bo die kerk, wat creatura verbi is. Die Skrif is immers die moederskoot van die kerk (Luther, WA 3:454; Calvyn, Inst. 1.7.2).

2.3 Die duplex ordo-model is te sien in die verhouding van die kerke tot teologiese opleiding aan die Nederlandse ryksuniversiteite en die Universiteit van Amsterdam (Douma, s.j.: 8-10) Die Nederlandse onderwyswet van 1876 bepaal dat die teologiese fakulteit voortaan gestruktureer sal word as 'n fakulteit van die godsdienswetenskap, die Godsbewussyn in die mens en die wyse van Godsverering. Terselfdertyd word ruimte aan die kerk gebied om kerklike leerstoele aan hierdie fakulteite te vestig. Hierdie ... "kromme constructie ... dwingt de studenten zich te oefenen in de crisis van het christendom en te leven in de spanning tussen menselijke religieusiteit en christelijk geloof. De schaduwzijden zijn: het uiteenvallen van exegese in de zogenaamde strikt-wetenschappelijke en bijbelse theologie; het 
misverstand dat er onderscheiden zou moeten worden tussen universitaire en kerkelijke theologie ..." (Wentsel, 1981: 24). Hierdie model is tans aangepas "met gelijkberechtiging van de kerkelijke vakken" (Heitink, 1992: 542).

In hierdie tweeslagtige kompromisopset is die sekularisme en rasionalisme van die Verligting duidelik sigbaar (kyk Elert, 1921:11-15).

Histories gesien, het die teologie uit die kerk ontstaan en staan dit in diens van die kerk. Daarom is 'n a-konfessionele beoefening van 'teologie ter wille van teologie' meestal onvrugbaar vir die volk van God - en bowendien soms gevaarlik (Heyns \& Jonker, 1977:188-189).

Uit bogenoemde modelle is dit duidelik dat die siening van die verhouding van kerk en teologie afhanklik is van die opvatting van die verhouding van kerk en Skrif. Bowendien word die verhouding óók bepaal deur die opvatting van wat kerk en wat wetenskap (i.c. teologie) is. 'n Bespreking van die kerkbegrip val buite bestek van hierdie artikel. Daarom moet voorts aandag gegee word aan teologie.

\section{Wat is teologie?}

\subsection{Pogings tot ' $n$ begripsomskrywing}

Die vraag wat teologie is, is meer kompleks as wat dit op die oog af lyk en dit het in die geskiedenis verskillende antwoorde ontlok. Ouweneel (1993: 36-43) gee 'n oorsig van die opvattings van wat teologie is en deel die opvattings met hulle onderskeie variasies en aksente in vier groepe in:

(i) Teologie is die studie van God.

(ii) Teologie is die wetenskap wat die Woord van God bestudeer.

(iii) Teologie bestudeer die geskrewe openbaring van God.

(iv) Teologie bestudeer die godsdienstige bewussyn van die mens.

Uit die feit dat daar verskillende definisies van teologie is, lei Ouweneel (1993:36) af: ..."'theological' definitions of theology clearly show their defectiveness" en konkludeer, met 'n beroep op Troost, "that theology (sic!) as such does not know what theology is in the sense of the philosophy of science" (Ouweneel, 1993:35). Die implikasie is dat slegs die filosowe kan sê wat teologie is. Die argument is egter disputabel want filosowe verskil óók onderling oor wat filosofie is. Beteken dit dat filo- 
sowe nie weet wat filosofie is nie? Watter ander 'superwetenskap' moet dan aan filosowe sê wat filosofie is?

Daar is, histories gesien, ook ander indelings van antwoorde op wat teologie is (kyk bv. Jonker se indeling in Malan, 1977:5-6; Douma, s.j.:7-8).

Die vraag is nou: kan ons bepaal wat teologie is? Dit lê voor die hand om die betekenis van die term uit die konnotasie daarvan af te lei, of om dit uit die historiese gebruik te bepaal.

Die betekenis van die woord teologie bring ons nie veel verder op die weg van 'n betekenisbepaling nie. Theologia kan taalkundig sowel die praat van God (subjek) as die praat oor God (objek) beteken (Wentsel, 1981:18; Heyns, 1992:26).

'n Historiese oorsig van die gebruik van die begrip teologie help ook nie en lei wéér na dit wat Ouweneel reeds in verband met die kontemporêre toneel aangetoon het, naamlik dat teologie verskillende betekenisse kan hê. In die antieke Grieks-Romeinse wêreld was theologia die spreek oor die gode en gevolglik gelyk aan mitologie, wat deur Plato en Aristoteles soms as eerste filosofie of metafisika aangedui en só van natuurfilosofie onderskei is (Feenstra, 1958:249; Wentsel, 1981:26-27; Heyns, 1992: 24). Teologie as selfstandige naamwoord kom nie in die Nuwe Testament voor nie. Die Oosterse kerk het gaandeweg hierdie heidens-mitologiese term 'gedoop' (Luther) en met 'n Christelike inhoud gevul. Eusebius van Caesarea (265-339) gebruik byvoorbeeld dikwels die term om die belydenis van God as Skepper en Logos aan te dui. In die lig van die himniese belydenis van Christus se Godheid word teologie later in die Oosterse Ortodoksie ' $n$ aanduiding van die belydenis van die drie-enige God. Hy wat die Triniteit bely, is ' $n$ teoloog.

In die Weste het die term eers betreklik laat (9de eeu) ingang gevind as aanduiding van die deurdink van die Christelike waarheid volgens die dialektiese metode. Vroeg in die 13de eeu word daar aan die universiteit van Parys gepraat van facultas theologia, waarmee die wetenskaplike beoefening van die teologie aangedui word. Daarna ontwikkel teologie tot 'n wydvertakte wetenskap met verskeie dissiplines binne die geheel van die wetenskappe. Die basiese betekenis van die term bly Godgeleerdheid. In ons eeu het 'n verengde begrip na vore gekom: teologie word die aanduiding van die opvattinge van 'n Bybelskrywer (bv. die teologie van Paulus) of van 'n groep gelowiges (gemeenteteologie). Soms dui die woord ' $n$ bepaalde geestestroming aan (bv. eksistensieteologie) en word selfs as sino- 
niem vir teoretiese besinning oor bepaalde sosiale vraagstukke gebruik, byvoorbeeld in die teologie van bevryding, die teologie van rewolusie en die feministiese teologie (vgl. vir bogenoemde oorsig Ebeling, 1962:754769; Metz, 1965:62-63; Wentsel, 1981:26-28).

\subsection{Afleidings}

Uit die voorgaande is dit duidelik dat nóg 'n woordstudie van teologie, nóg 'n historiese oorsig van die gebruik van die begrip, nóg 'n kontemporêre analise van definisies ' $n$ antwoord bied op die vraag wat teologie is.

Bogenoemde oorsig maak ons egter tog 'n paar dinge wys wat na my mening belangrik genoeg is om aan te toon.

\section{- Teologie as Godgeleerdheid}

Ouweneel se voorbeelde van definisies van teologie bly, by alle verskille, tog nog in die 'semantiese veld' van die Middeleeuse betekenis van Godgeleerdheid. ' $n$ Bepaalde kontinuiteit in die opvatting van wat teologie is, word hier sigbaar - 'n gegewe wat nie goed te rym is met Kuhn (1970) se historistiese visie op periodieke rewolusies wat in wetenskaplike 'paradigmas' voorkom nie.

\section{- Die disintegrasie van godsdiens en kultuur}

Die vertakking van die teologie in onderskeie dissiplines gedurende die later Middeleeue vind plaas binne die universitas scientiarum, die geheel van die wetenskappe. Dit is bekend dat die Wysbegeerte van die Wetsidee die bevoorregte posisie wat die teologie as regina scientiarum hier beklee het, sien as uitdrukking van ' $n$ tweeverdiepingvisie op natuur en genade. Hierdie dualisme is inderdaad teenwoordig. Daar is egter ook 'n ánder perspektief moontlik, naamlik om in die organiese ontwikkeling van die Middeleeuse wetenskap die uitdrukking te sien van 'n kultuur wat religieus geïntegreer was. Religieuse integrasie van die kultuur (en daarmee van die hele lewe) word ook in die tradisionele Afrika-kulture gevind, waar iets soos byvoorbeeld "kuns ter wille van die kuns" nie bestaan nie en "Negerkuns ... uiting van 'n wêreld- en lewensbeskouing" is (Werth, 1973: 126).

Die religieuse integrasie van die Middeleeuse kultuur, waar die hele lewe en alle kultuuruitinge in diens van God gestaan het (ongelukkig in die onsuiwer gestalte van kerklike oorheersing van die lewe), het tydens die Renaissance verlore geraak. Dán begin die proses van disintegrasie van 
godsdiens en kultuur. Renaissance is wedergeboorte en geen rewolusie nie. Daarom begin die proses van disintegrasie aarselend, soos blyk uit die blywende kunswerke van twee tydgenote, naamlik die groot samevatter van die Middeleeuse vokale polifonie, Palestrina (1525-1595), en die profetiese ysbreker en universele kunstenaar (skilder, argitek, ingenieur) Michelangelo (1475-1564). “... while Palestrina's name stands as the symbol of Catholic church music, and of 'old' music in general" (Láng, 1941:230), word die innerlike spanning in die kuns van Michelangelo reeds duidelik sigbaar. Láng (1941:321-322) tipeer dit só:

The strong metaphysical impulse that we knew in the Gothic world reappears in his works, but the opposing motives are not brought into harmonic unison ... The wondrous gigantic bodies created by his imagination will remain the symbols of captivity in matter, of a longing and desire for transcendental purity.

Hiér, in die kuns van Michelangelo, en in die Renaissance as geheel, kom die tweeverdiepingvisie in al sy krag na vore: die dichotomie van kerk en wêreld, van geloof en rede, van godsdiens en lewe (kultuur, wetenskap). Die wêreld, die lewe en die rede trek die skaal af: Anselmus (1033-1109) se fides quaerit intellectum en credo ut intelligam slaan by Descartes (1596-1650) se cogito ergo sum in sy teendeel oor. Uit die denke word die eie bestaan asook dié van God en die wêreld gepostuleer.

Midde in die branding staan die eensame bergpiek van die Reformasie. Saam met die Renaissance word die Middeleeuse kerklike oorheersing afgeskud. Maar anders as die Renaissance, wat die lewe onafhanlik van die kerk verklaar, soek die Reformatore na die religieuse integrasie van lewe en kultuur deur die heerskappy van die Woord van God. Zwingli, byvoorbeeld, verwag die vernuwing van die gedegenereerde en vermaterialiseerde Switserse samelewing alleen van die krag van die Woord en sê van die Woord: "For truly, truly, it will take its course as surely as does the Rhine. It may well be checked for a while, but never stopped" (Locher, 1981:110). En hy sien die transformerende krag van die evangelie in die lewe van mense "wat uitnemend vorder ... in liefde tot God, in vrede met hulle naaste, in kennis van die evangelie, in eenvoud van lewe ... in die gee van aalmoese en hulp aan die armes, in afbraak van hulle hoogmoed, in vergewing van hulle vyande ...' (Zwingli, 1940, 3:58; eie vert.).

Die Reformasie moes in die tyd van konsolidasie en in sy stryd teen die Roomse kontra-reformasie veg met die wetenskaplike wapens wat gemeenskaplik voor hande was, naamlik dié uit die arsenaal van die sko- 
lastiek (Beardslee, 1977:7 e.v.; kyk ook Torrance, 1969:36). Gevolglik het die Protestantse teologie grootliks 'n rasionele bedryf geword (wat later 'n reaksie in die vorm van piëtisme opgeroep het).

Hoe dit ook al sy, die disintegrasieproses van religie en kultuur wat in die Renaissance begin het, het die oorhand gekry. Selfs teologie word 'n bedryf van die rede. Die tweeverdiepinghuis is stewig gebou. Ons sien dit onder andere daarin dat musici nog tot die einde van die $18 \mathrm{de}$ eeu by één van die twee heersende instansies in diens was: of in die onderste verdieping van die adel, byvoorbeeld Josef Haydn (1732-1809) of in die boonste verdieping van die kerk, soos J.S. Bach (1685-1750) in sy later lewe. Die Franse Revolusie en Kant (1724-1804) se mondigverklaring van die mens het 'n nuwe impetus aan die humanisme gegee, wat in die Romantiek onder andere gestalte kry in die veridealisering van die kunstenaar - 'n eteriese wese wat nie meer musiek 'op aanvraag' skep nie maar wag op 'inspirasie'. Daarmee saam verander die kunstenaar se sosiale posisie én die opvatting van wat kuns is. Laasgenoemde word verabsoluteer tot 'kuns ter wille van die kuns' (l'art pour l'art). Die veranderde sosiale posisie van die kunstenaar sien ons afgeteken in die lewe van Mozart (17561791), wat 'te vroeg' die diens van aartsbiskop Colloredo van Salzburg verlaat en gevolglik in armoede moes voortsukkel; in die lewe van Haydn, wat sedert 1790 suksesvol op eie bene gestaan het; én by Beethoven (1770-1827), wat by niemand in diens was nie (vgl. Human, 1993:145).

Die verandering in kunsbegrip het sy parallel in 'n veranderde teologiebegrip in ons eeu. Dit kom op sy duidelikste uit in die sogenaamde teologieë van die genitief. Teologie het tradisioneel Godgeleerdheid beteken. In die uitgang -logie sit reeds ' $n$ implisiete genitief: teologie is geleerdheid (kennis) van God soos antropologie kennis van die mens is. Maar wat gemaak met ' $n$ dubbele genitief: kennis van God van die rewolusie? Laasgenoemde is 'n onmoontlike logiese en taalkundige konstruksie, wat onteenseglik aantoon dat die begrip teologie in die genitiefteologieë ' $n$ fundamentele betekeniswysiging ondergaan het en nie meer Godgeleerdheid kán wees nie - eerder die blote oortuiging van 'n groep of 'n persoon in verband met sosio-ekonomiese sake.

Die aanvanklike disintegrasie van religie en kultuur het gevolglik gelei tot 'n voortgaande versplintering van die lewe en kultuurskepping: die onderste verdieping is al meer in hokkies opgedeel. 
Die wetenskaplike en die wetenskap sélf het natuurlik bogenoemde disintegrasieproses ook nie vrygespring nie.

Omdat teologie in die algemeen as wetenskap beskou word, is dit nodig om iets oor wetenskap op te merk.

\section{Wat is wetenskap}

\subsection{Wetenskapsleer}

Die vraag 'wat is wetenskap?' hoort tuis in die wetenskapsleer of wetenskapsteorie, wat hom met die wetenskap sélf besig hou en die aard, terrein, metodes en grense van die wetenskap ondersoek. Die Wysbegeerte van die Wetsidee leer dat die voorgaande vraag asook die wetenskapsleer uitsluitend tot die domein van die Wysbegeerte behoort. Daarteenoor stel Heyns en Jonker (1977:17) dat wetenskapsleer 'n "interwetenskaplike dissipline" is, waar elke vakwetenskap sy eie wetenskapsleer in oorleg met die wysbegeerte moet opstel. Die wisselwerking is nodig omdat wetenskapsleer as dissipline van wysbegeerte nie alleen oor wetenskapsvrae kán en mág beslis nie. Die wysbegeerte wat voorgee om dit wel te kan doen, oorskry sy grense en bedreig elke ander wetenskap. Toegepas op die teologie, stel Heyns en Jonker (1977:16-17) die saak soos volg:

Hoe sal die teologie byvoorbeeld, ooit genoeë kan neem om van die wysbegeerte sy identiteit as wetenskap te ontvang? Watter wetenskaplike bydrae kan die wysbegeerte ooit lewer as daar mense arbei wat of geen teologiese skoling gehad het nie, óf meen dat hulle ná een of meer boeke oor die teologie gelees het, uitsprake oor die teologie as wetenskap kan maak? Dit is 'n gevaarlike pan-filosofisme wat alle ander wetenskappe wil verswelg.

Op bogenoemde indringende vrae het die Wysbegeerte van die Wetsidee tot op hede geen antwoord gegee nie. Inteendeel, vanuit hulle sisteem hou selfs 'n resente skrywer soos Ouweneel (1993:35) vol: "theology as such does not know what theology is in the sense of the philosophy of science" (let op die panfilosofiese term: wetenskapsleer of wetenskapsteorie word nou 'wetenskapsfilosofie' - philosophy of science). As die Wysbegeerte van die Wetsidee dan wel aan ons vertel wat "theology as such" is, word die gedagte dat teologie Godgeleerdheid is (a 'science of God') as konserwatief-skolasties afgewys (Ouweneel, 1993:37). Teologie is ook nie die studie van die Woord van God nie, want die Woord van God is vir almal (en vir alle wetenskaplikes) as studievoorwerp toeganklik. 
Die Woord van God is immers 'n "three-fold Word" (Spykman, 1991:1112), naamlik Skeppingswoord, vleesgeworde Woord, Skrifgeworde Woord. By Ouweneel (1993:253) word die Woord selfs 'n sesvoudige Woord (skeppingswoord, bewaringswoord, verlossingswoord, vleesgeworde Woord, Skrifgeworde Woord en gepredikte Woord; vgl. ook Heyns, 1992:80-82). Die 'gestaltes' van die Woord kan ad libitum uitgebrei word: verlossingswoord veronderstel byvoorbeeld oordeelswoord. Bestraffings- en bemoedigingswoord kan ook onderskei word. Dit is duidelik dat Woord hier in sy metaforiese en letterlike betekenis verwar word.

Die antwoord van die Wysbegeerte van die Wetsidee op wat teologie as sodanig is, is dat dit ' $\mathrm{n}$ vakwetenskap is wat die pistiese modaliteit van die werklikheid bestudeer. Studie van die geloofswetskring impliseer egter studie van geloof as algemeen menslike funksie. Daarmee word teologie as wetenskap in terme van die 19de-eeuse liberale teologie as studie van godsdiens (geloof), of van vergelykende godsdienswetenskap gekwalifiseer, waarvan die Christelike geloof ' $n$ onderdeel is.

\subsection{Wetenskapsleer is populêr}

Bavinck (1928:82) het reeds daarop gewys dat die aksent op die vóórvrae (prolegomena) van die dogmatiek in die 19de eeu 'n bepaalde rasionalisme en deisme veronderstel, wat die behandeling van die inhoud van die dogmatiek verskraal het. Bavinck (1928:81) wys in hierdie verband op die invloed van die filosofie op die teologie en sê:

Maar nog grooter verandering kwam er in den vorm der dogmatiek door den invloed der wijsbegeerte. Vooral hierin komt dit uit, dat de eigelijke materieele dogmatiek hoe langer hoe armer werd, en de pars formalis in omvang en uitgebreidheid steeds toenam.

Ná 'n (hoofsaaklik) eksistensialistiese tussenspel gedurende die eerste helfte van ons eeu keer die 19de-eeuse visie en problematiek in die laaste helfte van die 20ste eeu terug. Daar is sedert die sestigerjare weer 'n ongekende aksent op die vóórvrae van die dogmatiek - tot so 'n mate dat Kamphuis (1988:8) dit tipeer as "een ziekte-symptoom van de huidige theologie". Hierdie belangstelling is ingebed in die algemene belangstelling in wetenskapsleer en in die wetenskaplike karakter van die teologie (Pannenberg, 1977). Die belangstelling in wetenskapsleer verraai soms 'n kenteoretiese krisis wat die verstaansprobleem in die algemeen van oorheersende belang maak. Daarom word hermeneutiek die kardinale wetenskap - nie net in die teologie nie (Kuitert, 1966:37-90; Pannenberg, 1977: 
278-298), maar soms ook in ander wetenskappe, byvoorbeeld die filosofie en die taalwetenskappe (Nethersole, 1982:147). Jennings waarsku tereg dat die oormatige aksent op teoretiese en metodiese vrae 'n proses kan wees "in danger of becoming an obsessional neurosis" (in De Villiers, 1991:145), terwyl De Villiers (1991:146) ons wesentlik weer by Bavinck se standpunt bring as hy sê: "An interest in theory and methodology has the inherent weakness of becoming self-centred and consequently, selfdefeating."

Ten slotte is die vasgryp aan hermeneutiek 'n krisissimptoom. Nethersole (1982:147) stel dit só:

However, there is undoubtedly much truth in the widely held belief that hermeneutics gains in interest and emphasis at times of crises, or to be more exact at those moments in history when established world-views flounder and the intellect find it necessary to legitimise inherited traditions - as is the case with Gadamer - or to radically criticise them, as Habermas does.

Die aksent op die wetenskapsleer - veral die kenteorie - wys gevolglik ook op die disintegrasie van die Westerse kultuur.

\subsection{Teologie as wetenskap ${ }^{1}$}

Wanneer die Renaissance die dubbelverdiepinghuis (as plan latent in die Middeleeue) begin bou, val die lewe en Westerse kultuur finaal uiteen in twee dele: kerk en wêreld, geloof en rede, godsdiens en wetenskap. Ná die Reformasie gly die Protestantse teologie van die boonste verdieping af ondertoe. Eintlik is laasgenoemde sin valse beeldspraak, wat reggestel moet word deur te sê: tydens die konstruksie van die dubbelverdieping van die Renaissance-humanisme het die Reformasie 'n enkelverdieping gebou waarin geloof en lewe 'n eenheid gevorm het. Die Westerling het egter die dubbelverdieping meer bewoonbaar gevind. Deur die toedoen van Descartes en die Protestanse Ortodoksie is die Middeleeuse plan finaal goedgekeur en 'n glybaan van die boonste verdieping na onder gekonstrueer. Die insig in die historiese karakter van die dogma (Semmler) en van die Christelike godsdiens (Lessing) het die finale hupstoot aan die teologie

i 'n Historiese oorsig van die wisselende opvattings van die wetenskaplikheid van teologie val buite bestek van hierdie artikel. Kyk hieroor bv. Stellingwerff, 1971, Pannenberg, 1977:226-277. Vir die Barth-Scholtz-debat, kyk Molendijk, 1992: 527-545. 
gegee om af te gly (Lohse, 1966:226-230). Teologie word deel van die 'wêreld': 'n rasionele bedryf wat die Skrif histories-krities dissekteer.

Wanneer Kant die mens mondig verklaar het, word die kunstenaar in die 19de-eeuse Romantiek veridealiseer as 'n eteriese wese wat slegs kuns op (subjektiewe) inspirasie kan skep. Kuns is dan nie meer ars of technê, dit wil sê lewensambag wat op aanvraag geskep word nie, maar dit is "die allerindividueelste ekspressie van die allerindividueelste emosie" (Kloos; kyk Van der Elst et al., 1988:267).

Kant het egter méér gedoen: hy het God en onsterflikheid as 'grensbegrippe' van die praktiese rede gepostuleer en op dié manier God vir ons wetenskaplike kennis van die wêreld oorbodig gemaak. Gevolglik het die wetenskaplikheid van teologie 'n probleem geword. Schleiermacher (1768-1834) het die probleem wat Kant gestel het, probeer oplos deur 'n nuwe aprioriese fundering van die godsdiens (en teologie) binne die empiries bestudeerbare werklikheid te soek en het dit in die gevoel van die mens gevind (Bromiley, 1978:362; Torrance, 1969:44).

Schleiermacher was dié teoloog van die Romantiek. Die Romantiek se versubjektivering van die kuns dra hy oor op die teologie (kyk Elert, 1921: $58-66)$.

\subsection{Teologie as wetenskap: moderne reddingspogings}

Schleiermacher se poging om die wetenskaplikheid van die teologie te red, was die eerste maar nie die laaste nie. In ons eeu het die logiese positivisme van die Wiener Kreis ('n teenstroom teen die eksistensialisme) opnuut die empiriese karakter van wetenskap beklemtoon. In die lig van hierdie filosofie word enkele moderne pogings om die wetenskaplikheid van die teologie te red, aan die orde gestel. Die sprekende beeld wat Mackay noem, word gebruik en uitgebrei.

In A Preface to Christian Theology onderskei John Mackay (in Packer, 1987:5, 6) twee tipes interesse in Bybelse sake, geillustreer deur balkonsitters en padgebruikers. Eersgenoemde sien die padgebruikers, hoor hulle praat en kan selfs met die reisigers gesels. Die balkonsitters kan opmerkings maak oor die manier waarop sommige reisigers loop, oor die konsekwensies wat kom as die reisigers by die vurk in die pad vorentoe links in plaas van regs gaan. Hulle bly egter toekykers en hou hulle met bloot teoretiese probleme besig. Die reisigers daarenteen, het ook teoretiese beslissings om te maak, maar dis verbind en in diens van praktiese 
sake: hoe kom ons by ons bestemming? Die balkonsitters en reisigers kan selfs oor dieselfde kennisgebiede dink, maar hulle vrae en probleme verskil. In verband met die sonde en die kwaad byvoorbeeld, is die balkonsitters se probleem hoe die bestaan van die kwaad met God se almag en goedheid gerym kan word en of die verdorwenheid van die mens empiries bewysbaar en gevolglik geloofwaardig is. Daarenteen is die probleem van die reisigers wat hulle eie vuilheid bemerk, eerder dit wat in Heidelbergse Kategismus vraag 2 gesê word: "hoe ek van my sonde en ellende verlos kan word".

Teoloë is vandag behep om op die balkon te sit. Die mense wat die teoloë op die balkon gehelp het, en wat self daar sit, is die logies-positivistiese filosowe. Húlle het op die verhewe meta-vlak van die balkon gaan sit en vir die reisigers (vakwetenskaplikes) gesê: Dis nie óns taak as filosowe om uitsprake oor die werklikheid te maak nie, maar om slegs julle uitsprake op hulle waarheidsgehalte te toets. Ons loop nie die pad nie maar kyk slegs of julle reg loop.

'n Bekende teoloog wat deur die logiese positiviste op die balkon getel is, is Kuitert. Hy wil deur middel van afstandneming en kritiese refleksie die status en waarheidsgehalte van die is-sinne van die godsdiens in die algemeen en van die Christendom in die besonder ondersoek. Die resultaat van die analise moet daartoe lei dat 'meer en meer gelowige mense tot volwasse en mondige Christene uitgroei wat die is-sinne van die Christelike geloof beaam - of nie beaam nie - omdat en vir sover hulle die waarheid daarvan self insien en ervaar' (Kuitert, 1977:16 - my vertaling; kyk ook 1977:911). Só word die mens gehelp om tot mondigheid te kom. As ons egter bloot glo op gesag van buite af, bly ons eintlik onmondig. En op grond van ons mondige insig in die 'historiese karakter' van die Skrif kan die opvatting van 'geopenbaarde waarheid' verwerp word (Kuitert, 1977: 15). Die teologie bied vir ons bloot proposisies, wat nie geopenbaarde waarhede is nie maar empiries ervaarbare waarhede (in natuur en geskiedenis) wat deur mense geformuleer is. Die taak van die teologie is (soos die taak van die filosofie by die logiese positivisme) om hierdie proposisies op hulle waarheidsgehalte te toets.

Ook John Hick (1977:177) analiseer op meta-vlak van die balkon af die Christelike geloofsuitsprake en vra na aanleiding van die twee-nature-leer:

Is it a factual statement (a combined statement, presumably, about empirical and mataphysical facts), or does it express a commitment, or make a value 
judgment: and is its meaning literal, or metaphorical, or symbolic or mythological, or poetic, ...?

Volgens Hick (1977:178) kan die formule 'God en mens' geen letterlike betekenis hê nie: "It remains a form of word without assignable meaning" - soos die stelling dat 'n sirkel tegelyk 'n vierkant is. Hick (1977:178) se konklusie is dat dit 'n mitologiese uitspraak is waarin die kerk sy commitment teenoor Jesus uitspreek.

Ondertussen is die balkonsittery van teoloë in die mode. Ons sien dit in die toenemende aantal studies oor die prolegomena van die teologie - iets waarna reeds verwys is.

\subsection{Samevatting}

Die vraag 'Wat is wetenskap?' is ten slotte nog nie beantwoord nie. Uit die vorige uiteensetting is dit duidelik dat die antwoord deur filosofiese en wêreldbeskoulike uitgangspunte bepaal word. Gevolglik is daar in die wetenskapsleer ' $n$ hele aantal definisies van wetenskap in omloop.

Wat egter duidelik is, is dat die modeme pogings om die wetenskaplikheid van die teologie te red geskoei is op 'n wetenskapsopvatting wat aan die 19de eeu ontleen is. Hiervolgens vind wetenskap sy ideaalbeeld in die eksakte natuurwetenskappe wat 'n kousale, geslote wêreldbeeld veronderstel (Elert, 1921:188-195) en rus op Newton se verouderde fisika (Stoker, 1993:23-24; Torrance, 1969:58). Soos beginsels (Stoker) of vóóronderstellings die visie op wat wetenskap is, bepaal, beslis dit ook oor die metode, doel en grense van die wetenskap. Wat die metode betref ${ }^{2}$, wys Stoker (1940:302) op "... die teenswoordige vergoding (selfgenoegsaamstelling) van die eksperimentele metode, waarin die prinsipiële perke en prinsipe-gebondenheid van die metode nie raak gesien word nie." Hy vervolg:

Die eksperimentele (ja elke) metode in die hande van twee wetenskaplikes met verskillende beginselinsigte lei tot verskillende resultate; die eksperimentele metode kan oor beginselonderskeidinge nie beslis nie.

Is 'n definisie van wetenskap en van teologie überhaupt moontlik? Nee nie solank ons teen die mure van die onderste verdieping van die huis (die wêreld) bly vaskyk nie. Dán gaan elkeen sy eie vertrekkie afpen en die res

2 Metodeleer (metodologie) kan hier nie nader uitgewerk word nie. Kyk hieroor bv. Heyns en Jonker, 1977:37-42; Stoker, 1940:301-303; 1961:52-107; 1970:181-201; Van der Merwe, 1983:331-335; vir teologiese metodes: Bavinck, 1928:36-71; Van Til, 1974:8-20. 
van die wêreld vanuit sy (verabsoluteerde) hoekie besien (só ontstaan die -ismes). Dit is hierdie toedrag van sake wat die hoofkarakter in Pirsig (1984:107) se boek in die volgende wet formuleer: "The number of rational hypotheses that can explain any given phenomenon is infinite." Hierdie 'wet' van relativisme, ingeklee in geleerde terme soos 'sosiale paradigmavorming' en 'verstaanshorison' (kyk ook Bernstein, 1983:171 e.v.) het wetenskap as wete in die asblik laat beland. Pirsig (1984:108) stel die effek daarvan skerp:

If true, that law is not a minor flaw in scientific reasoning. The law is completely nihilistic. It is a catastrophic logical disproof of the general validity of all scientific method!

Die relativisme van die -ismes is vererger deur ' $n$ bepaalde -isme wat in die 19de ceu dominant geword het - die historisme. Historisme is kultuur-historiese ewolusionisme (Klapwijk, 1970:50), wat vrug is van die onwrikbare geloof in die vooruitgang van die mensheid - "de religie van de vooruitgang" (Van Niftrik, 1966:11). Pirsig (1984:108) vat die leer van die historisme, wat waarheid tydgebonde ag, in 'n formule saam: waarheid is 'n funksie van tyd $(\mathrm{w}=\mathrm{ft})$. Met behulp van dié formule word die korrespondensieteorie van waarheid agterhaal en foundationalism die nek omgedraai. Maar daarmee saam is "the most basic presumption of all science" óók vernietig (Pirsig, 1984:108).

Die kulturele disintegrasie van die Weste versand ten slotte in die postmodernisme met sy pluralisme en radikale relativisme. Die enigste absolute vertrekpunt waarvan uitgegaan word, is dat alles relatief is (Cooper, 1993: 109).

Die enigste uitweg uit die impasse is 'n Archimedespunt buite die wêreld, wat die wêreld in sy aard en eenheid kan sien. Hierdie Archimedespunt bied God in sy Woord aan ons.

\section{Grondslag}

\subsection{Grondslag of fondament?}

Dis bekend dat die Vrije Universiteit sy oorspronklike grondslag (die drie Formuliere van Eenheid) gaan herbenoem het as fondament (nl. die Christelike godsdiens). Daarmee is beweeg van die spesifieke, die duidelik geformuleerde (nl. die konfessie) na die algemene, die vae en onomlynde ('Christelike godsdiens'). Dieselfde retrogressiewe beweging is in voor- 
beelde van moderne hersienings van die konfessie sigbaar (Van Til, 1974: 4).

Grondslag en fondament is dus nie dieselfde nie. Trouens, dis Bybelse wysheid. 'n Mens kan 'n huis met fondament en al enige plek oprig, maar dan word op die sandgrond van valse sekerheid, van menslike outonomie gebou. As die stormwinde en die reëns kom, sak die huis van so 'n dwase man inmekaar. Die wyse man, daarenteen, wat die leer van Christus ter harte neem, bou sy huis op één spesifieke plek, naamlik op 'n rots (Matt. 7:24:27).

\subsection{Nader omskrywing van grondslag 3}

Die grondslag van die gereformeerde teologie is die Woord van God wat die kerk in aansyn geroep het en waardeur kerk én teologie hulle bestaan en voortbestaan vind. Die evangeliewoord is immers 'n krag van God tot saligheid (Rom. 1:16) en die profetiese Woord is baie vas en skyn soos 'n lamp in 'n donker plek (1 Pet. 1:19). Die skepsel in al sy glorie en heerlikheid (Matt. 6:28-30) - óók die mens met sy kennis en kundigheid - is verganklik 4 . Teenoor die verganklikheid van die skepsel hou die Woord van God in ewigheid stand (Jes. 40:8; 1 Pet. 1:24-25).

'n Breër omskrywing van die grondslag van die teologie, naamlik as die openbaring van God, deug nie in die lig van die Skrif nie. Hoewel God Hom deur middel van sy werke en sy Woord aan die mense bekend maak (art. 2 NGB), het die natuurlike mens die moedswilligheid om dit wat hy in hom en om hom van God se werk kan opmerk, te verdraai en die ewige God in die gestalte van 'n skepsel voor te stel (Rom. 1:19-23). Treffend teken Calvyn (Inst. 1.5.4) hierdie moedswilligheid van die sondaarmens:

Hoe afstootlik - bid ek jou - is hierdie kranksinnigheid nie, dat die mens God honderd maal in eie liggaam en siel aantref en tog juis onder die dekmantel van sy uitnemendheid verklaar dat God nie bestaan nie?

Die resultaat van die menslike moedswilligheid is sigbaar in die empiriese gegewe van 'n veelheid van godsdienste. Maar hierdie goddelose gods-

3 Hier volg hoofsaaklik 'n tetiese uiteensetting. Die -ismes se 'kleuring' van die grondslag, soos byvoorbeeld in verskillende modelle van Skrifopenbaring na vore kom (kyk Kelsey, 1975:14-58), lê buite die omvang van hierdie artikel.

4 Onvergeetlik toonset Brahms in Ein deutches Requiem (1868) hierdie waarheid in die vorm van 'n dodemars "Denn alles Fleisch es ist wie Gras". 
dienstigheid van die mensdom lê onder die óprì $\theta \varepsilon \circ \hat{v}$ (Rom. 1:18) wat van die hemel af dáárin bekend word dat Hy hulle oorgee aan hulle eie vermeende outonome begeertes (Rom. 1:24, 26).

Juis dáárom is teologie as vergelykende godsdienswetenskap, wat vandag weer in aanvraag is (Kamstra, 1992:184-187), uit die staanspoor vir die gereformeerde teologie 'n onmoontlike en onwettige onderneming. As die teologie hom moet besig hou met menslike godsdienstigheid (of met die mens as religieuse wese), versand die teologie in antropologie en godsdienspsigologie. Dán het die lewende God uit die gesigsveld verdwyn.

Ten slotte nóg 'n opmerking: artikel 2 van die NGB praat skriftuurlike taal en sê dat God Hom deur twee middele aan ons bekend maak, te wete deur sy werke en deur sy Woord. 'n Aardse analogie kan dit wat hier ter sprake is, verduidelik. Ek kan aan studente my gedagtes oordra deur middel van wat ek doen (gebare, skemas op die swartbord, modelle wat geteken word) en wat ek sê. As die studente half blind is of moedswillig hulle oë sluit en dit wat ek doen, verkeerd interpreteer (Rom. 1:21-23), kan ek nog altyd hulle my woorde maak hoor en so met 'n beter hulpmiddel (Calvyn) my gedagtes aan hulle oordra. Die twee maniere van doen (dade en woorde) het egter geen ontiese status as twee verskillende dinge nie. Dit is die gebrek van die voorstaanders van die Wysbegeerte van die Wetsidee dat hulle tereg die éénheid van die openbaring wil vashou maar in die twee middele van openbaring (art. 2 NGB) die skolastieke dualisme van die dubbelverdiepinghuis wil inlees. Ondertusssen hou hulle nie genoeg rekening met die feit dat die duideliker en meer volkome Woordopenbaring as 'beter hulpmiddel' (Calvyn) vanweë die blindheid en moedswilligheid van die mens gegee is nie. Die sondige verdorwenheid van die mens word gevolglik in die Wysbegeerte van die Wetsidee opvallend onderbeklemtoon.

\section{3 'n Konfessionele grondslag}

Die aanvaarding van die geskrewe Woord van God as grondslag van die teologie is sélf geen wetenskaplik-teoretiese hipotese nie maar voorwetenskaplike eksistensieel-reële vertrekpunt, wat die Gees deur die Woord self werk en die begronding van die teologie in die Woord noodsaaklik maak. My (geloofs-) aanvaarding van die realiteit dat ek my ouers se kind is, geskied op gesag van hulle woord, is nie afdoende met rasionele argumente of selfs met empiriese DNA-toetse 'bewysbaar' nie maar begrond desnieteenstaande my identiteit binne die sosiale lewe. Op analoë wyse 'weet' 
die gelowiges (kerk) op gesag van God se Woord dat hulle sy kinders is, dat Hy hulle en alle dinge geskep het (vgl. Luther se Klein Kategismus) en dat Hy die soewereine God is wat alles dra. Aan hierdie (geloofs)wete en aanvaarding van wat God in sy Woord sê, gee gelowiges gestalte in 'n belydenis van hulle geloof. Olthuis (1976:1) stel dit só:

Our appeal to the Scriptures takes the form of a confession. We confess that it is in the Scriptures that we come to know Christ ... In faith we bow before the Scriptures as the Word of God. That we cannot go behind or beyond the Scriptures to test their authority as the Word of God is no problem. If there was some higher authority by which to corroborate the Scriptures, the Scriptures would not be the Word of Canon for the new creation, the First and Last Word. (Vgl. oor die konfessionele ruimte Heyns, 1992:35-36.)

Die skeppende krag van die evangelie waarkragtens die kerk bestaan, én die gevolglike kennis van God wat in die konfessie weerklank vind, het verreikende noëtiese en kenteoretiese implikasies wat wag om nader uitgestippel te word (kyk die panoramiese buitelyne wat Van Til (1974:1-61) reeds in dié verband getrek het). In soverre Calvyn hom terloops met kenteoretiese sake besig gehou het, is dit duidelik dat kennis van God menslike kennis met behulp van die outonome rede veroordeel. Torrance (1965:97) som Calvyn se visie só op:

If we are really to know God truly we must be emancipated from self-will for self-will determines de profundis all our own ways of knowing and thinking. We need a truth that will set us free from ourselves, otherwise we ourselves with all our preconceptions, prejudgments and inventions, will distort knowledge of God and from the very start convert it into untruth.

Wanneer die soewereine God nie erken word nie, maar een of ander aspek van die kosmos verabsoluteer word, bly die filosofie én vakwetenskappe worstel met onoplosbare antinomieë, byvoorbeeld dié van natuurwetmatigheid en menslike vryheid (die en soi en pour soi van Sartre!) en dié van toevalligheid en wetmatigheid (bv. by die naturalisme en ewolusionisme).

\subsection{Omskrywings}

God Drie-enig is Skepper en Onderhouer van alle dinge. Hy is die bron van kennis en wysheid. In sy wysheid het hy 'n kenbare kosmos en 'n kennende mens geskep - laasgenoemde as sy beeld, óók daarin dat die mens in betreklike sin kan ken. Torrance (1969:60) stel dit só:

The creation acquires its rationality in God's creative comprehension of it, that it is constituted and enabled to be the rational medium through which God speaks to us and makes Himself known, and in which once and for all His own eternal Word has become man. 
Teen bogenoemde agtergrond kan wetenskap omskryf word as die menslike handeling waardeur hy die kenbare werklikheid ondersoek, kennis versamel, sistematiseer en kontroleer ten einde kultuurskeppend (in toegepaste kennis) oor die skepping te heers. Omdat die mens se kennis betreklik is en sy hart en verstand boonop as gevolg van die sonde verduister is (Rom. 1:21; Ef. 4:18) moet wetenskaplike kennis voortdurend aan die kenbare gekontroleer word en is dit in beginsel oop vir hersiening.

In die lig van bogenoemde word elke vorm van verabsolutering van menslike dink en doen afgewys: geen l'art pour l'art nie, geen wetenskap ter wille van die wetenskap nie, geen "wetenskaplike metodisme" (Stoker, 1970:195-196) nie.

Teologie is die wetenskaplike bestudering van die Woord van God om só tot kennis van God en van sy verhouding tot alle dinge te kom. Dit veronderstel die kenbaarheid van die Woord as openbaringsmiddel, dit wil sê dat God verstaanbaar met die mens kommunikeer. Daarom kan teologie in ' $n$ bepaalde sin wel as Godgeleerdheid omskryf word. Hiermee word teologie as neutrale en objektiewe rasionele Bybelkennis afgewys, terwyl die Bybel as openbaringsmiddel die opvatting dat teologie die transendente onbegryplike God sélf as 'studievoorwerp' sou hê, by die wortel afsny.

Teologie dra óók die voorlopigheid en betreklikheid van alle wetenskaplike kennis en derhalwe moet teologiese kennis voortdurend aan die Woord as "positiewe gegewe vir die wetenskap" (Stoker, 1940:300) getoets word.

Soos God één is, is sy openbaring één - al kom die openbaring ná die sondeval na ons óók in die Woordgestalte as "beter hulpmiddel" (Calvyn, Inst. 1.6.1). Ten slotte is dit die één God wat Hom in sy werke én in sy Woord openbaar. Dáárom het elke wetenskap, gekonfronteer met die werke van God, ten slotte 'n 'teologiese dimensie' en die teologie 'n 'kosmiese dimensie', want die Woord spreek van die werke van God.

In die eenheid van die wetenskap lê die wisselwerking van die wetenskappe ingebed. Op sy beurt weerspieël die eenheid van die wetenskap die eenheid van lewe en kultuur - 'n lewe en kultuur wat deur die krag van die evangeliewoord getransformeer en opnuut religieus geintegreer word.

In die doel van elke wetenskap lê nie net kennisversameling en -gebruik nie, maar ook 'n doksologiese moment. Op die ewige lofsegging van die Skepper stuur alle dinge af (Op. 4:11); ja, elke skepsel sal "met alles wat 
in hom is" (Op. 5:13) God se lof verkondig. Totius berym die kosmiese lofsang in aangrypende versmaat (Skrifberyming 8 verse 4(b) en 5(a)):

En al wat leef en roer, al die geskape dinge op aarde en diep omlaag, of in die hoë hemel, al wat die see bewoon en in sy dieptes wemel die ganse skepping sing met krag van jubeltoon: 'Aan Hom wat heerlik is, hoog op die wêreldtroon, en aan die Lam van God, self eewge Skeppings-Here, sy ewig lof en prys en krag en roem en ere'.

\section{Bibliografie}

AGENDA VAN DIE VYF-EN-VEERTIGSTE NASIONALE SINODE TE POTCHEFSTROOM, 1994.

BAVINCK, H. 1928. Gereformeerde dogmatiek. DI. 1. 4de dr. Kampen : Kok. BEARDSLEE, J.W. 1977. Reformed Dogmatics. Grand Rapids : Baker.

BERNSTEIN, R.J. 1983. Beyond Objectivism and Relativism: Science, Hermeneutics and Praxis. Oxford : Basil Blackwell.

BIBLIA SACRA IUXTA VULGATAM VERSIONEM. 1975. Zweite verb. Aufl. Stuttgart : Würtembergische Bibelanstalt.

BROMILEY, G.W. 1978. Historical Theology. Grand Rapids : Eerdmans.

CALVYN, J. 1984. Institusie van die Christelike godsdiens. Boek 1. Vertaal deur H.W. Simpson. Potchefstroom : CJBF.

CILLlÉ, G.G. 1983. Waar kom ons Afrikaanse Gesange vandaan? Kaapstad : NG Kerk-Uitgewers.

COOPER, J.W. 1993. Reformed Apologetics and the Challenge of Post-Modern Relativism. Calvin Theological Journal, 28(1):108-120.

DE VILLIERS, P.G.R. 1991. The End of Hermeneutics? On New Testament Studies and Postmodernism. Neotestamentica, 25(1):145-156.

DOUMA, J. s.j. Encyclopedie. (In Douma e.a. s.j. Oriëntatie in de Theologie. Barneveld : De Vuurbaak. p. 12-18.)

EBELING, G. 1962. Theologie. (In Die Religion in Geschichte und Gegenwart 6:754-769.)

ELERT, W. 1921. Der Kampf um das Christentum. München : Beck.

FEENSTRA, Y. 1958. Godgeleerdheid. (In Christelijke Encyclopedie 3:249250.)

HEITINK, G. 1992. Ontwikkelingen in de praktische theologie. Praktische Theologie, 19(4):538-557.

HEYNS, J.A. 1992. Inleiding tot die dogmatiek. Halfway House : NG Kerkboekhandel.

HEYNS, J.A. \& JONKER, W.D. 1977. Op weg met die teologie. 2de dr. Pretoria : N.G. Kerkboekhandel.

HICK, J. 1977. Jesus and the World Religions. (In Hick, J. ed. The Myth of God Incarnate. 2nd. ed. London : SCM Press.) 
HUMAN, K. 1993. Die A tot Z van klassieke musiek. 2de dr. Kaapstad : Human \& Rousseau.

KAMPHUIS, B. 1988. Klare taal. De duidelijkheid van de Schrift. Barneveld : De Vuurbaak.

KAMSTRA, J.H. 1992. De plaats van de godsdienstwetenschap in de theologie. Nederlands Theologisch Tijdschrift, 46(3):338-557.

KELSEY, D.H. 1975. The Uses of Scripture in Recent Theology. Philadelphia : Fortress Press.

KLAPWIJK, J. 1970. Tussen historisme en relativisme. Assen : Van Gorkum.

KRUGER, L.S. e.a. 1966. Handleiding by die Kerkorde. Potchefstroom : Pro Rege.

KUHN, T.S. 1970. The Structure of Scientific Revolutions. 2nd ed. Chicago : University of Chicago.

KUITERT, H.M. 1966. De realiteit van het geloof. Kampen : Kok.

KUITERT, H.M. 1977. Wat heet geloven? 2de dr. Baam : Ten Have.

LÁNG, P.H. 1941. Music in Western Civihzation. New York : Norton.

LOCHER, G.W. 1981. Zwingli's Thought. New Perspectives. Leiden : Brill.

LOHSE, B. 1966. A Short History of Christian Doctrine. Transl. by F.E. Stoeffler. Philadelphia : Fortress Press.

LUTHER, M. 1912. D. Martin Luthers Werke. Kritische Gesamtausgabe (Weimarer Ausgabe). Weimar : Böhlaus 1867. (Unveränderter Abstruck, 1912.)

MALAN, C.J. 1977. Kerk en teologie (opsomming van referate gelewer by die G.E.S.). In die Skriflig, 11(42):5-9.

METZ, J.B. 1965. Theologie. (In Lexicon fur Theologie und Kirche, 10:6271.)

MOLENDIJK, A.L. 1992. Ein "heidnischer" Wissenschaftsbegriff? Der Streit zwischen Heinrich Scholz und Karl Barth um die Wissenschaftlichkeit der Theologie. Evangelische Theologie, 52(6):527-545.

NEDERLANDSE GELOOFSBELYDENIS. 1987. In Die berymde Psalms en Skrifberymings 2de her. uitg. Kaapstad : N.G. Kerk-Uitgewers. p. 486-520. NETHERSOLE, R. 1982. Literary Hemeneutics: A Theory for Understanding Texts. (In Ryan, R. \& Van Zyl, S. eds. An Introduction to ContempoNGB rary Literary Theory. Johannesburg : Donker. p. 147-160.)

$k y k$

NEDERLANDSE GELOOFSBELYDENIS.

OLTHUIS, J.H. 1976. The Word of God and Biblical Authority. Potchefstroom : IRS. (Wetenskaplike bydraes van die PU vir CHO, reeks Fl, Studiestuk nr. 101.)

OUWENEEL, W.J. 1993. A Critical Analysis of the External and Internal Prolegomena of Systematic Theology. Bloemfontein : UOFS. (D.Th. Thesis.) 
PACKER, J.I. 1987. Knowing God. 16th impr. London : Hodder \& Stoughton.

PANNENBERG, W. 1977. Wissenschaftstheorie und Theologie. Frankfurt a.M : Suhrkamp.

PIRSIG, R.M. 1984. Zen and the Art of Motorcycle Maintenance. (Corgy edition).

SCHULZE, L.F. 1966. Straatsburg en artikel 2 van die Dordtse Kerkorde. Koers, 33(4):310-314.

SPOELSTRA, B. 1989. Gereformeerde kerkreg en kerkregering. Hammanskraal : Die Hammanskraalse Teologiese Skool.

SPYKMAN, G. 1991. Spectacles. Repr. Potchefstroom : PU vir CHO.

STELLINGWERFF, J. 1971. Inleiding tot de universiteit. Amsterdam : Buijten en Schipperheijn.

STOKER, H.G. 1940. Beginsels van 'n Christelike wetenskapsleer. (In Koers in die krisis 2. Stellenbosch : Pro Ecclesia. p. 293-331.)

STOKER, H.G. 1961. Beginsels en metodes in die Wetenskap. Potchefstroom : Pro Rege.

STOKER, H.G. 1970. Outlines of a Deontology of Scientific Method. (In Stoker, H.G. Oorsprong en rigting 2. Kaapstad : Tafelberg. p. 181-201.)

STOKER, P.H. 1993. Die nuwe wetenskap. Die Kerkblad, 96(2930):22-24.

TORRANCE, T.F. 1965. Knowledge of God and Speech about Him according to John Calvin. (In Mehl, R. ed. Regards Contemporaines sur Jean Calvin. Paris : Presses universitaires. p. 77-98.)

TORRANCE, T.F. 1969. Space, Time and Incamation: London : Oxford University Press.

VAN DER ELST, e.a. 1988. Momente in die Nederlandse letterkunde. Pretoria : Academia.

VAN DER MERWE, N.T. 1983. Rationality and Scripture: Outline of a Philosophical Approach. (In Hart, H. e.a. eds. Rationality in the Calvinian Tradition. Lanham University Press of America. p. 319-359.)

VAN NIFTRIK, G.C. 1966. De vooruitgang der mensheid. Nijkerk : Callenbach.

VAN TIL, C. 1974. An Introduction to Systematic Theology. Phillipsburg : Presbyterian and Reformed.

VG.

$k y k$

VULGAAT.

WA

$k y k$

D. Martin Luthers Werke.

WENTSEL, B. 1981. Het Woord, de Zoon en de Dienst. Dogmatiek, deel I. Kampen : Kok. 
WERTH, A.J. 1973. Die invloed van primitivisme op die beeldende kunste met besondere verwysing na Suidelike Afrika. Pretoria : UP. (D.Phil.proefskrif).

ZWINGLI, H. 1940. Hauptschriften, Bd. 3. Bearbeitet von F. Blanke, O. Farner, R. Pfister. Zürich : Zwingli-Verlag. 
